\title{
AKTUALISASI PENDIDIKAN MODERASI BERAGAMA DI MADRASAH
}

\author{
Muhamad Syaikhul Alim, Achmad Munib \\ Mahasiswa Program Doktor PAI Nusantara Unwahas \\ Email: alimsyaikhu1078@gmail.com, kafabihi@unwahas.ac.id
}

\begin{abstract}
:
This article describes Religious Moderation Education in Islam, especially about the portrait and development of religious moderation education in madrasas. The crucial issues to be answered regarding moderation education in Islam in Madrasahs are (1) What is meant by religious moderation? (2) What are the characteristics of religious moderation in Islam? (3) and how is the portrait and development of religious moderation education in madrasas? To answer this problem, library research is carried out by exploring various literatures in the form of books, articles, journals, scientific opinions related to Islamic moderation to then be analyzed descriptively. The findings of this study include: Islamic moderation is understood as a balance between strong beliefs and tolerance in which there are Islamic values that are built on the basis of a straight and moderate mindset and not excessive. Madrasas are seen as one of the Islamic educational institutions that have succeeded in bringing moderate Islam in their educational praxis, therefore they deserve to be examples of religious moderation education for other educational institutions. To strengthen madrasas, they can develop mainstreaming of Islamic moderation, among others through: formulating a vision and mission oriented towards Islamic moderation, developing a comprehensive curriculum that incorporates Islamic moderation values, optimizing habituation and madrasa culture as a strategy for internalizing Islamic moderation character values, and developing programs strengthening Islamic moderation.

Keywords: Education, Religious Moderation, Madrasah.

Abstrak:

Artikel ini memaparkan Pendidikan Moderasi Beragama dalam Islam khususnya tentang potret dan pengembangan pendidikan moderasi beragama di madrasah. Adapun permasalahan krusial yang hendak dijawab terkait pendidikan moderasi dalam Islam di Madrasah yakni (1) Apa yang dimaksud moderasi beragama? (2) Bagaimanakah karakteristik moderasi beragama dalam Islam? (3) dan bagaimanakah potret dan pengembangan pendidikan moderasi beragama di madrasah?Untuk menjawab masalah tersebut ditempuh penelitian kepustakaan (library research) dengan melakukan eksplorasi berbagai literatur baik berupa buku-
\end{abstract}


buku, artikel, jurnal, opini ilmiah terkait moderasi Islam untuk kemudian dianalisis secara deskriptif. Temuan dari kajian ini antara lain: Moderasi Islam dipahami sebagai keseimbangan antara keyakinan yang kokoh dengan toleransi yang di dalamnya terdapat nilai-nilai Islam yang dibangun atas dasar pola pikir yang lurus dan pertengahan serta tidak berlebihan. Madrasah dipandang sebagai salah satu institusi pendidikan Islam yang berhasilmembawakan Islam moderat dalam praksis pendidikannyakarenanya layak menjadi contoh pendidikan moderasi beragama bagi institusi pendidikan lainnya. Untuk memantapkan madrasah dapat mengembangkan pengarusutamaan moderasi islam antara lain melalui: perumusan visi dan misi berorientasi moderasi Islam, pengembangan kurikulum yang komprehensif yang menginsersi nilai-nilai moderasi Islam, Optimalisasi habituasi dan budaya madrasah sebagai strategi internalisasi nilai-nilai karakter moderasi Islam, dan mengembangkan program penguatan moderasi Islam.

Kata Kunci : Pendidikan, Moderasi beragama, Madrasah.

\section{A. PENDAHULUAN}

Masyarakat Indonesia dikenal sebagai masyarakat majemuk (plural) dan beraneka ragam (heterogen). Kemajemukan dan keragaman masyarakat Indonesia ditandai oleh berbagai perbedaan baik horizontal seperti suku, bahasa dan adat-istiadat maupun vertikal menyangkut relasi spiritual. ${ }^{1}$ Pluralitas merupakan realitas sejarah dan keniscayaan bagi masyarakat Indonesia. Kemajemukan ini menjadi sesuatu yang khas dan tidak dapat dipisahkah dari kemanusiaan itu sendiri seperti pelangi yang berwarna-warni. Keanekaragaman adalah keserasian dan keindahan tersendiri. Ia bukanlah kekacauan dan kesemrawutan. Keanekaragaman tidak bisa dilawan, ia akan selalu ada, ia adalah sunnatullah. ${ }^{2}$

Pada kenyataannya, karakteristik keanekagaraman dan perbedaan yang dimiliki bangsa Indonesia adalah sebuah dilema. Di satu sisi kondisi ini merupakan kekayaan yang tak ternilai namun di sisi yang

${ }^{1}$ Said Agil Husain Al-Munawwar, Fikih Hubungan Antar Agama, (Jakarta: Ciputat Press, 2005), viii.

${ }^{2}$ Nurcholish Madjid, Pluralitas Agama: Kerukunan dalam Keragaman, (Jakarta: Kompas, 2001), x. 
lain bisa menjadi potensi petaka dan bencana. Pluralitas dan heterogenitas bisa menjadi berkah bagi bangsa Indonesia jika mampu menjadi modal yang mengantarkan Indonesia menjadi bangsa besar sebagai multicultural nastion-state. Bangsa yang mampu hidup damai dan harmonis di tengah perbedaan. Namun demikian di sisi lain, keunikan multietnis dan multikultural seperti Indonesia dihadapkan pada permasalahan yakni munculnya potensi ancaman. Keragaman masyarakat multikultural ini sangat rawan memicu konflik dan perpecahan. ${ }^{3}$

Adalah sebuah kenyataan munculnya gerakan-gerakan yang mengancam eksistensi negara karena mengarah pada sikap eksklusif, intoleran, rigid, mudah mengkafirkan, mudah menyatakan permusuhan (irhabiyah) yang belakangan berkembang cukup pesat di tanah air ini. Di samping itu, semakin berkembang pula adanya gerakan interpretasi terhadap nash secara berlebihan, keluar dari makna teks yang sebenarnya, permisif, liberal, menggugat nash-nash qat'i dan menginterpretasikan berdasarkan seleranya. ${ }^{4}$

Pascareformasi terjadi eskalasi yang cukup mencengangkan dalam kehidupan sosial keagamaan di Indonesia. Data dan fakta meningkatnya kasus intoleransi, Menguatnya politik identitas dengan sentimen keagamaan. Terjadinya kerusuhan berlatar belakang agama di berbagai daerah seperti di Maluku dan Poso. Munculnya paham radikalisme dan terorisme. Fenomena semakin banyak ASN dan kalangan pelajar/mahasiswa terpapar faham radikalisme merupakan gambaran faktual yang mendukung pada satu kesimpulan bahwa kita sesungguhnya sudah berada pada level darurat.

\footnotetext{
${ }^{3}$ Nasikun, Sistem Sosial Indonesia, (Jakarta: Raja Grafindo Persada, 2007), 33.

${ }^{4}$ M. Cholil Nafis dkk., Islam Wasathiyyah, (Jakarta: Komisi Dakwah MUI, 2019), iii.
} 
Setara Institute mencatat pelanggaran atau kekerasan kebebasan beragama dan berkeyakinan di Indonesia pada 2018 naik dibandingkan dengan tahun lalu. Setara mencatat hingga Juni 2018 ada 109 intoleransi_dalam kebebasan beragama dan berkeyakinan. ${ }^{5}$ Temuan senada juga diungkap peneliti LIPI, Amin Mudzakkir bahwa terjadi peningkatan dalam intoleransi di Indonesia terutama yang berkaitan dengan isu-isu politik. Dari berbagai macam data yang LIPI kumpulkan, muncul tiga faktor penyebab intoleransi sangat tinggi. Pertama, karena muncul tingginya rasa terancam terhadap agama lain yang menyebabkan dis-trust. Kedua, tingginya fanatisme keagamaan dan ketiga karena pengaruh media sosial. ${ }^{6}$

Sementara itu riset yang dilakukan Maarif Institute (2011), Setara Institute (2015), dan Wahid Foundation (2016) menunjukkan bahwa kelompok-kelompok radikal telah secara masif melakukan penetrasi pandangan radikal di kalangan generasi muda melalui institusi pendidikan. Kemudian, diperkuat beberapa survei yang menunjukkan bahwa siswa maupun mahasiswa kecenderungan sikap intoleransi dan radikalisme cukup mengkhawatirkan, guru pun demikian. Gejala intoleransi dan radikalisme berbasis agama akan cenderung menunjukkan eskalasi lebih besar.

Menguatnya fenomena intoleransi dan radikalisme sebagaimana di atas, membuat banyak orang kemudian mempersoalkan peran pendidikan, sebagai salah satu wahana pembentuk sikap keberagamaan, pendidikan sudah seharusnya menjadi basis perhatian seluruh stakeholder bangsa ini. Sebagaimana kutipan

5 https://nasional.tempo.co/read/1118802/setara-institut-intoleransi-terhadapkeyakinan-meningkat, diakses Selasa, 17 Nopember 2020 pukul 17.44 WIB.

https://www.merdeka.com/politik/lipi-temukan-fakta-intoleransi-meningkat-diindonesia.html, diakses Selasa, 17 Nopember 2020 Pukul 17.55 WIB. 
dari seorang remaja Islam peraih nobel perdamaian Malala Yousafzai, "peluru hanya bisa menewaskan teroris, tapi hanya pendidikan-lah yang bisa melenyapkan faham terorisme sampai ke akar-akarnya (radikalisme-ekstrimisme)"

Madrasah sebagai salah satu model pendidikan Islam sejauh ini telah menunjukkan keberhasilan dalam menanamkan karakter moderat dalam pemikiran maupun praktik beragamaannya. Potret dan praktik pendidikan ala madrasah perlu diangkat dan diperkenalkan kepada khalayak luas sehingga bisa menjadi prototype dan model bagaimana moderasi beragama ditanamkan kepada siswa-siswa madrasah.

Untuk itu artikel ini akan mengangkat masalah yang penting terkait moderasi beragama dalam Islam meliputi : (1) Apa yang dimaksud Pendidikan moderasi beragama? (2) Bagaimanakah karakteristik moderasi beragama dalam Islam? (3) dan bagaimanakah potret dan pengembangan pendidikan moderasi beragama di madrasah?

Penulisan artikel ini termasuk library research, karena itu langkah-langkah yang akan dilakukan adalah eksplorasi terhadap sejumlah data dari berbagai literatur, baik data primer, maupun data sekunder. Metode pengumpulan data dilakukan dengan mengumpulkan buku-buku, artikel, jurnal, opini ilmiah yang didalamnya mengungkap dan mengkaji wasatiyah. Adapun teknik analisa data dengan menggunakan metode deskriptif-analitik. Data yang telah dianalisis kemudian dipaparkan dengan metode deduktif yang berangkat dari teori umum untuk menuju pada kesimpulan yang merupakan jawaban dari rumusan masalah penelitian.

\section{B. DISKUSI DAN PEMBAHASAN}

\section{Pengertian Pendidikan Moderasi Beragama}


Dari tinjauan etimologis, kata moderasi merupakan kata serapan dari moderation dari kata sifat moderate yang artinya not extreme; limited artinya tidak ekstrim atau terbatas. ${ }^{7}$ Dalam bahasa arab digunakan istilah wasatiyyah sebagai padanan dari kata moderasi. Kata wasatiyyah mengandung arti وسط الثيء ما بين طرفيه artinya : sesuatu yang berada (di tengah) di antara dua sisi. ${ }^{8}$ Dari pengertian etimologis ini dapat disimpulkan bahwa kata moderasi diartikan sikap berada di tengah-tengah serta menjaga diri dari sikap melampaui batas.

Secara terminologis, menurut Ma'ruf Amin, makna kata "wasatan" yaitu pertengahan sebagai keseimbangan (al-tawazun), yakni keseimbangan antara dua jalan atau dua arah yang saling berhadapan atau bertentangan: spiritualitas (ruhiyah) dengan material (maddiyah), individualitas (fardiyyah) dengan kolektivitas (jama'iyyah), kontekstual dengan tekstual, konsisten (sabat) dengan perubahan (tagayyur). ${ }^{9}$

Menurut Din Syamsuddin konsep moderasi islam diinterpretasikan sebagai al-sirat al-mustaqim yang bertumpu pada tauhid sebagai ajaran Islam yang mendasar dan sekaligus menegakkan keseimbangan dalam penciptaan dan kesatuan dari segala lingkaran kesadaran manusia. ${ }^{10}$ Menurut Hasyim Muzadi, moderasi/wasatiyyah artinya: "Wasatiyyah adalah keseimbangan antara keyakinan (yang kokoh) dengan toleransi".

${ }^{7}$ Martin H. Manser, Oxford Learner's Dictionary, (Oxford: Oxford University Press, 1991), 267.

${ }^{8}$ Pendapat ini disampaikan Muhammad bin Mukrim bin Mandhur al-Afriqy al-Masry sebagaimana dikutip oleh M. Cholil Nafis dkk, Islam Wasathiyah, 1. Pendapat yang senada juga dikemukakan para ulama seperti Ibnu Asyur, Al-Asfahany dan wahbah Al-Zuhaili yang intinya mengartikan kata wasat berada di tengah-tengah dalam arti menjaga dari sikap melampaui batas (ifrat) dan ekstrem (tafrit).

${ }^{9}$ Nafis dkk, Islam Wasathiyah, 4.

${ }^{10}$ Nafis dkk, Islam Wasathiyah, 4. 
Syarat untuk merealisasikan sikap wasatiyyah yang baik memerlukan akidah dan toleransi, sedangkan untuk dapat merealisasikan akidah dan toleransi yang baik memerlukan sikap yang wasatiyyah. ${ }^{11}$

Berdasarkan beberapa pengertian tersebut pemaknaan moderasi (wasatiyyah) dapat dipadukan sebagai keseimbangan antara keyakinan yang kokoh dengan toleransi yang di dalamnya terdapat nilai-nilai Islam yang dibangun atas dasar pola pikir yang lurus dan pertengahan serta tidak berlebihan. Keseimbangan tersebut bisa terlihat dengan kemampuan mensinergikan antara dimensi spiritualitas dengan material, individualitas dengan kolektivitas, tekstual dengan kontekstual, konsistensi dengan perubahan dan meletakkan amal di dalam prinsip-prinsip keseimbangan antara theocentris dan anthropocentris.

Moderasi Islam (Wasatiyyat Islam) adalah suatu corak pemahaman dan praksis Islam. Ia juga merupakan suatu metode atau pendekatan dalam mengkontekstualisasi Islam di tengah peradaban global. Kehadiran Wasatiyyat Islam sangat perlu dan dibutuhkan baik di lingkungan umat Islam sendiri, maupun di tengah pergulatan Islam dengan beragam agama dan sistem dunia lainnya. $^{12}$

Wasatiyat Islam yang sesungguhnya sudah secara historis dan kultural menjadi warna dasar keberagaman umat Islam di Indonesia. Hal ini mengejawantah pada keberadaan ratusan ormas dan lembaga Islam yang tersebar di seluruh pelosok Indonesia sekaligus menjadi ciri khas Islam di Indonesia. Organisasi-organisasi Islam ini

${ }^{11}$ Nafis dkk, Islam Wasathiyah, 5.

${ }^{12}$ Kantor Utusan Khusus Presiden untuk Dialog dan Kerjasama Antar Agama dan Peradaban, Wasatiyyat Islam Untuk Peradaban Dunia: Konsepsi dan Implementasi, (Jakarta: KUKP, 2018), 7. 
merupakan organisasi massa dan gerakan kebudayaan sekaligus. Inilah yang telah menjadi tulang punggung berdirinya negara Republik Indonesia yang rancang bangunnya pada tingkat tertentu dapat dipandang sebagai manifestasi wasatiyat Islam. ${ }^{13}$

Paham keagaman moderat (al-wasathiyah fil-Islam) penting untuk terus digemakan dan disosialisasikan kepada sebanyak mungkin masyarakat. Sehingga dapat menjadi kontra narasi dari klaim kelompok tertentu yang menyebarkan paham radikalisme. Saat ini, kelompok ini menyebarkan faham dan keyakinannya tersebut melalui halaqah, penyebaran pamflet, buletin, propaganda di media sosial dan sebagainya. Sampai titik ini, kegiatan yang dilakukan kelompok ini dapat dikategorikan sebagai radikal dalam ide dan gagasan (radical in mind) yang dapat menjadi ancaman dan perlu diwaspadai karena sewaktu-waktu dapat berubah menjadi radikal dalam gerakan (radical in action). ${ }^{14}$

Pendidikan pada dasarnya interaksi manusia bertemu dengan keragaman manusia baik keragamaman agama, etnis dan ras. ${ }^{15}$ Pendidikan seharusnya berpengaruh pada nilai-nilai moderasi beragama pada siswa yang didapatkan dari berbagai sumber literasi,

Suardi mengungkapkan bahwa pendidikan moderasi beragama sebuah usaha memahami dan menumbuhkan pemahaman pada keberagaman agama, (mazhab) etnis, ras dan budaya. ${ }^{16}$ Sementara Muhammad Ahnaf menyatakan pendidikan Islam hendaknya dapat

${ }^{13}$ Kantor Utusan Khusus Presiden untuk Dialog dan Kerjasama Antar Agama dan Peradaban, Wasatiyyat Islam, 8.

${ }^{14}$ M. Cholil Nafis, dkk, Islam Wasathiyyah, viii. 2003), 102.

${ }^{15}$ Hasan Langgulung, Azas-azas Pendidikan Islam. (Jakarta : Pustaka Al Husna,

${ }^{16}$ Moh. Suardi, Ideologi Politik Pendidikan Kontemporer, (Yogyakarta, e-Publish: 2015), 55 . 
mempromosikan nilai toleransi dan penghargaan terhadap keragaman agama terletak tidak sebatas persoalan kurikulum, melainkan pada kemampuan otoritas sekolah dalam mengelola lingkungan dan ruang publik sekolah yang mendorong kebebasan dan tradisi berpikir secara kritis.

Dari beberapa penjelasan di atas dapat diambil konklusi bahwa pendidikan moderasi beragama adalah upaya sadar dalam memahami, menanamkan dan menumbuhkan pemahaman atas keberagaman agama, etnis, ras dan budaya melalui berbagai macam pendekatan, strategi dan metode yang tepat sehingga tumbuh sikap dan perilaku moderat yang tercermin dalam nilai-nilai moderasi beragama antara lain, penghargaan terhadap keragaman, toleransi, moderat, keseimbangan, dan keadilan pada diri setiap peserta didik.

\section{Nilai-Nilai Moderasi Beragama dalam Islam}

Prinsip dan karakteristik moderasi Islam penting untuk diketengahkan, mengingat perlunya membuat pandangan yang jelas dan implementatif sebagai pemahaman dan praktik amaliyah keagamaan umat Islam dalam konteks kehidupan bermasyarakat, berbangsa dan bernegara. Tujuannya adalah agar nilai-nilai ajaran Islam Rahmatan li al-'alamin dapat melahirkan umat yang terbaik (khaira al-ummah).

Adapun beberapa ciri pemahaman dan praktik amaliyah keagamaan moderasi Islam yaitu:

a. Tawassut (mengambil jalan tengah), yaitu pemahaman dan pengamalan agama yang tidak ifrat (berlebih-lebihan dalam beragama) dan tafrit (mengurangi ajaran agama).

b. Tawazun (berkeseimbangan), yaitu pemahaman dan pengamalan agama secara seimbang yang meliputi semua aspek kehidupan, 
baik duniawi maupun ukhrawi; tegas dalam menyatakan prinsip yang dapat membedakan antara inhiraf (penyimpangan) dan ikhtilaf (perbedaan).

c. I'tidal (lurus dan tegas), yaitu menempatkan sesuatu pada tempatnya, melaksanakan hak dan memenuhi kewajiban dan tanggung jawab secara proporsional, bersikap tegas dan berpegang teguh pada prinsip.

d. Tasamuh (toleransi), yaitu mengakui dan menghormati perbedaan, baik dalam aspek keagamaan dan berbagai aspek kehidupan lainnya dan oleh karena itu wasatiyyat menuntut sikap fair dan berada di atas semua kelompok/golongan.

e. Musawah (egaliter), yaitu tidak bersikap diskriminatif pada yang lain disebabkan perbedaan keyakinan, status sosialekonomi, tradisi, asal usul seseorang, dan atau gender.

f. Syura (musyawarah), yaitu menyelesaikan persoalan dengan jalan musyawarah untuk mencapai mufakat dengan prinsip menempatkan kemaslahatan di atas segalanya.

g. Ishlah (reformasi), yaitu mengutamakan prinsip reformatif untuk mencapai keadaan lebih baik yang mengakomodasi perubahan dan kemajuan zaman dengan berpijak pada kemaslahatan umum (mashlahah 'ammah) dengan tetap berpegang pada prinsip al-muhafazah 'ala al-qadimi al-salih wa al-akhdzu bi al-jadid al-aslah.

h. Aulawiyah (mendahulukan yang prioritas), yaitu kemampuan mengidentifikasi hal ihwal yang lebih penting harus diutamakan untuk diimplementasikan dibandingkan dengan yang kepentingan lebih rendah. 
i. Tatawwur wa ibtikar (dinamis dan inovatif), yaitu selalu terbuka melakukan perubahan sesuai dengan perkembangan zaman serta menciptakan hal baru untuk kemaslahatan dan kemajuan umat manusia.

j. Tahadhdhur (berkeadaban), yaitu menjunjung tinggi akhlakul karimah, karakter, identitas, dan integritas sebagai khair ummah dalam kehidupan kemanusiaan dan peradaban.

k. Wathaniyah wa muwathanah, yaitu penerimaan eksistensi negara-bangsa (nation-state) di manapun berada dengan mengedepankan orientasi kewarganegaraan.

1. Qudwatiyah, yaitu melakukan kepeloporan dalam prakarsaprakarsa kebaikan demi kemaslahatan hidup manusia (common good and well-being) dan dengan demikian umat Islam yang mengamalkan Wasatiyat memberikan kesaksian (syahadah). ${ }^{17}$

Prinsip-prinsip di atas seyogyanya mengkristal dalam paradigma dan perilaku muslim baik individual maupun kolektif dalam berbagai aspek kehidupan sehingga terwujud masyarakat khaira ummah yang dapat mengejawantahkan Islam rahmatan li al'alamin yang membawa harmoni dan penuh kedamaian.

\section{Analisis Pendidikan Moderasi Beragama di Madrasah}

Lembaga pendidikan sangat tepat menjadi "laboratorium moderasi beragama". Seperti yang telah dipahami bahwa bangsa Indonesia merupakan bangsa yang memiliki ragam suku dan agama. Indonesia memiliki kekhasan yang unik, tetapi penuh dengan tantangan. Sekolah sebagai institusi pendidikan dapat menumbuhkan

${ }^{17}$ Rumusan ini merupakan hasil Musyawarah Nasional Majelis Ulama Indonesia (MUI) IX yang tertuang dalam TAUJIHAT SURABAYA yang diselenggarakan pada 8-11 Dzulqa'dah 1436 H/24-27 Agustus 2015. Lihat Nafis dkk, Islam Wasathiyah, 14-36. Lihat juga Kantor Urusan Khusus Presiden, Wasatiyyat Islam, 11-13. 
pola pikir moderasi beragama dengan kondisi bahwa pandangan eksklusif dan tindakan ekstremisme kekerasan dalam jubah agama akan merusak sendi serta tenun kebangsaan yang majemuk. ${ }^{18}$

Di sinilah pentingnya "batu pertama" moderasi beragama dibangun atas dasar filosofi universal dalam hubungan sosial kemanusiaan. Lembaga pendidikan menjadi sarana tepat guna menyebarkan sensitivitas peserta didik pada ragam perbedaan. Membuka ruang dialog, guru memberikan pemahaman bahwa agama membawa risalah cinta bukan benci dan sistem di sekolah leluasa pada perbedaan tersebut.Tidak hanya itu, pemerintah harus memimpin gerakan penguatan keberagamaan yang moderat sebagai arus utama, dengan mempromosikan pentingnya kehidupan beragama secara moderat sebagai panduan spiritual dan moral.

Mengingat tantangan faktual intoleransi yang semakin merebak bahkan menjurus kepada radikalisme maka pengarusutamaan moderasi Islam sebagai kontra narasi harus menjadi kesadaran, tanggung jawab dan gerakan kolektif segenap komponen bangsa. Di sinilah pentingnya lembaga pendidikan mengambil perannya dalam menyemai watak dan karakter toleran kepada anak didik sebagai generasi penerus bangsa. Di pundak lembaga pendidikan eksistensi negara dan bangsa Indonesia dipertaruhkan. Mampukah lembaga pendidikan kita dengan sistem pendidikan yang berjalan sementara ini membendung gelombang intoleransi yang mencabik-cabik kebhinnekaan yang selama ini kita jaga dan rawat dengan baik?

Madrasah sebagai bagian dari sistem pendidikan nasional diharapkan bisa tampil dan berbicara lebih banyak. Madrasah dan

${ }^{18}$ Edy Sutrisno, Aktualisasi Moderasi Beragama di Lembaga Pendidikan, dalam Jurnal Bimas Islam Vol 12 No. 1 (2019) http://jurnalbimasislam.kemenag.go.id 
lembaga pendidikan Islam seperti pesantren, diniyah, dan perguruan tinggi Islam adalah garda terdepan kampanye moderasi Islam di Indonesia. Apalagi, madrasah memiliki banyak kelebihan yang tak dimiliki sistem pendidikan lain. Madrasah selama ini juga sangat afirmatif terhadap kalangan rakyat yang rentan secara ekonomi, dibuktikan dengan biaya pendidikan yang murah terjangkau. Selain itu, kelebihan madrasah terletak pada fungsinya melahirkan kelas menengah muslim yang aware kepada nilai kebangsaan dan NKRI. ${ }^{19}$

Nilai-nilai moderasi Islam sebenarnya sudah menjadi praksis keseharian dunia madrasah, warga madrasah sudah terbiasa dan mengenal istilah tawasut (moderat), tawazun (proporsional), tasamuh (toleran) dan ta'adul (berlaku adil). Term-term tersebut tidak hanya diajarkan kepada peserta didik untuk dihafalkan tetapi sudah teraplikasi dalam wujud sikap dan perilaku sehari-hari. Namun seiring perkembangan zaman dan perubahan yang terjadi di masyarakat madrasah dituntut selalu berimprovisasi dengan inovasi dan kreatifitas baru mengingat tantangan merebaknya intoleransi semakin menguat dan potensi tingkat keterpaparan faham intoleransi juga semakin hebat terutama lewat pengaruh gencarnya propaganda di media sosial.

Di samping karena moderasi Islam sudah menjadi laku dan budaya segenap warga madrasah faktor lain yang cukup mendukung implementasi moderasi Islam di madrasah adalah komitmen kolektif dari segenap pemangku kepentingan (stakeholders) madrasah yang menjadi kekuatan tersendiri. Warga madrasah sangat konsen terhadap Islam yang ramah dan bukan Islam yang marah. Islam yang rahmatan li al-'alamin, Islam yang membawa kedamaian untuk seluruh dunia.

19 https://republika.co.id/berita/p639ta396/sebagai-garda-depan-moderasi-islam-inikelebihan-madrasah. Diakses Kamis, 12 Nopember 2020 pukul 23.52 WIB. 
Islam moderat sudah terbangun di dalam mindset warga madrasah. Sikap toleransi tampak dan termanifestasi dalam penghormatan terhadap adanya perbedaan. Sikap positif seperti ini harus terus menerus dipupuk sehingga semakin kokoh dan kuat. Selain itu komitmen terhadap bangsa dan negara juga tidak perlu diragukan lagi. Sudah menjadi mafhum bahwa kecintaan kepada tanah air merupakan sebagaian dari keimanan. Sehingga warga madrasah tidak mudah diprovokasi dengan interpretasi dan pemahaman yang menyimpang tentang hubungan antara agama dengan negara.

\section{Pengembangan Pendidikan Moderasi Beragama di Madrasah}

Kajian mengenai model pendekatan pendidikan moderasi beragama, misalnya dinyatakan Muhammad Ahnaf menyatakan bahwa tantangan lembaga pendidikan Islam dalam mempromosikan nilai toleransi dan penghargaan terhadap keragaman agama terletak tidak sebatas persoalan kurikulum, melainkan pada kemampuan otoritas sekolah dalam mengelola lingkungan dan ruang publik sekolah yang mendorong kebebasan dan tradisi berpikir secara kritis. Otoritas sekolah perlu memahami materi dan pola-pola penyebaran paham radikal di kalangan anak muda, terutama di lingkungan sekolah, sehingga potensi pengaruh paham radikal bisa diantisipasi secara efektif. ${ }^{20}$

Muhammad Najib Azca melakukan penelitian dengan judul 'The Younger, the Radical: Refleksi Sosiologis pada Fenomena Radikalisme Muslim Muda di Indonesia Pasca Orde Baru'. Dia mengusulkan salah satu cara terbaik untuk melawan gerakan

20 Ahnaf, M. I. (2013) 'Struktur politik dan deradikalisasi pendidikan agama bagi anak muda di Indonesia', Jurnal Pendidikan Islam. doi: 10.14421/jpi.2013.21.153171. 
keagamaan radikal pada orang muda adalah dengan menerapkan strategi ganda, yaitu mengembangkan diskusi kritis dan membangun wacana counter, ide dan narasi, dan mendukung dan mengembangkan hubungan sosial dan jaringan jamak. ${ }^{21}$

Murtadlo (2019a) dalam kajian tentang moderasi beragama pada lembaga pendidikan keagamaan pesantren dan Seminari di Jawa Timur (2019) merekomendasikan perlunya pendidikan moderasi beragama dikenalkan kepada anak muda sedini mungkin. Hal ini penting agar sedini mungkin anak muda Indonesia mengenal perbedaan, keragaman dan siap untuk hidup bersama (Murtadlo, 2019b). ${ }^{22}$

Peran guru di sekolah/madrasah sangat penting dalam mengenalkan moderasi beragama di sekolah/madrasah. Sedikit guru agama memberi peluang berkembangnya paham intoleran, maka hal itu akan menyumbang berkembangnya radikalisme agama di masyarakat secara luas.

Edy sutrisno mengutip buku Menjaga Benteng Kebhinekaan di Sekolah yang diterbitkan Maarif Institute, menyebut ada tiga pintu utama bagaimana pemahaman radikal dan intoleransi melakukan penetrasi di lingkungan sekolah; pertama, kegiatan ekstrakurikuler. Kedua, peran guru dalam proses belajar mengajar. Ketiga, melalui kebijakan sekolah yang lemah dalam mengontrol masuknya radikalisme di sekolah. Jika kita melihat data dan temuan tersebut, kecenderungan intoleransi dan menguatnya radikalisme di sekolah

21 Azca, M. N. (2013) 'Yang Muda, Yang Radikal: Refleksi Sosiologis Terhadap Fenomena Radikalisme Kaum Muda Muslim di Indonesia Pasca Orde Baru', Maarif, 8(1), pp. 14-44.

${ }_{22}$ Murtadlo, M. (2019a) Menakar Moderasi Beragama pada Perguruan Tinggi, Kemenag.go.id. Murtadlo, M. (2019b) Seminari dan Pengembangan Moderasi Beragama: Kajian terhadap Seminari Al Kitab Asia Tenggara (SAAT) Malang. Jakarta. Puslitbang Penda 
sudah sangat memprihatinkan. Oleh karena itu, di sinilah letak strategisnya pengarusutamaan moderasi beragama perlu dilakukan. ${ }^{23}$

Badan Nasional Penanggulangan Terorisme (BNPT), menyatakan sudah saatnya anak-anak muda diawasi dari kemungkinan keterpaparan dalam paham radikalisme. Utamanya terkait dengan aktivitas mereka di dunia maya. ia menjelaskan bahwa di era kemajuan teknologi informasi seperti saat ini, ajaranajaran radikal mudah disebarkan melalui internet. Karenanya beliau meminta agar anak-anak muda selalu di awasi orang tua minimal harus tahu situs-situs apa saja yang sering diakses oleh anakanaknya, jangan sampai mereka menjadi radikal karena mengakses internet tanpa ada pengawasan. Lebih lanjut BNPT mengatakan bahwa perkembangan internet membuka celah bagi masuk dan berkembangnya paham radikal, anak-anak muda yang mengakses informasi-informasi radikal itu disebutnya berpeluang sangat besar untuk menjadi radikal atau bahkan menjadi pelaku teror. Meski begitu beliau juga menyatakan bahwa internet tidak sepenuhnya buruk, karena melalui internet pula informasi yang baik dan benar terkait dengan agama dan nasionalisme dapat disebarluaskan ke masyarakat. $^{24}$

Diantara yang mencoba melontarkan pemikiran tentang pendidikan moderasi beragama pada anak muda, misalnya Masdar Hilmi yang menyampaikan: Pertama, negara perlu hadir mendesain materi dan metode deradikalisasi yang relevan dengan karakteristik psikologis anak muda. Harus diakui, program deradikalisasi di

${ }^{23}$ Edy Sutrisno, Aktualisasi Moderasi Beragama di Lembaga Pendidikan.

${ }^{24}$ BNPT (2016) Terkait Lone Wolf, kepala BNPT Minta Awasi Anak Muda. Available at: https://damailahindonesiaku.net/terkait-lone-wolf-kepala-bnpt-minta-awasianak-muda.html. 
negeri ini kurang mengakomodasi metode serta materi yang menggugah, inspiratif, dan relevan dengan kebutuhan psikologisintelektual anak muda. Sebab, target program deradikalisasi selama ini adalah kelompok usia dewasa. Kedua, perluasan jangkauan program deradikalisasi ke wilayah-wilayah yang selama ini dianggap privat seperti keluarga. Program deradikalisasi oleh BNPT selama ini hanya menyentuh ormas-ormas keagamaan dewasa yang jumlahnya terbatas. Dalam konteks ini, jumlah anak muda yang tidak terlibat dalam program deradikalisasi jauh lebih banyak. Ketiga, mengatasi dislokasi dan deprivasi sosial anak-anak muda melalui program pelibatan sosial. Selama ini, proses kognitif dan psikologis anak muda kurang terawasi dengan baik oleh orang-orang dewasa di sekitarnya. Mereka menjadi radikal karena komunikasi sosial mereka dengan orang-orang terdekat terputus. Solusinya, anak muda harus sesering-seringnya diajak berdialog dan berkomunikasi dengan orang dewasa. ${ }^{25}$

Dari beberapa analisis dan pemikiran di atas, untuk mengimplementasikan moderasi Islam di madrasah, di samping modal dukungan dan komitmen dari segenap stakeholders sebagai prasyarat diperlukan inovasi dan kreatifitas madrasah sehingga mampu menghadirkan konsep implementasi moderasi Islam yang konseptual, segar, menarik dan efektif. Beberapa strategi pengembangan berikut merupakan tawaran model pengarusutamaan moderasi Islam yang dapat diterapkan di madrasah antara lain:

1. Madrasah merumuskan visi dan misi berorientasi moderasi Islam.

${ }^{25}$ Hilmy, M. (2015) 'Anak Muda di Tengah Pusaran Radikalisme', Jawa Pos, 27 March. Available at: http://digilib.uinsby.ac.id/14245/1/Anak Muda Di Tengah Pusaran Radikalisme .pdf. 
Gerakan pengarusutamaan moderasi Islam harus berawal dari visi dan misi madrasah. Mengingat visi adalah pandangan jauh ke depan yang ideal tentang cita-cita yang diharapkan. Sedangkan misi adalah langkah-langkah operasional untuk mencapai visi. Sedapat mungkin visi dan misi yang dirumuskan ini menempatkan moderasi Islam ini sebagai bagian profil ideal yang diharapkan. Visi dan misi ini hendaknya tidak hanya sekedar menjadi pajangan atau tulisan belaka tetapi hendaknya menjadi ruh dan spirit yang terus menerus digelorakan sehingga menjiwai seluruh warga madrasah. Untuk itu visi dan misi madrasah harus dirumuskan bersama dan disosialisasikan kepada seluruh pemangku kepentingan madrasah

2. Madrasah mengembangkan kurikulum yang komprehensif dengan menginsersi nilai-nilai moderasi Islam.

Kurikulum bisa dikatakan merupakan ruh dalam pendidikan dan pembelajaran. Hendak dibawa kemana peserta didik tercermin sepenuhnya dari muatan kurikulum yang dikembangkan dan diterapkan oleh madrasah. Cara yang bisa ditempuh dengan jalan madrasah menelaah kurikulum yang saat ini sedang diterapkan, mengidentifikasi kelemahan yang mungkin masih ada untuk kemudian merancang kurikulum secara lebih komprehensif yang diharapkan bernuansa nilainilai moderasi Islam. Standar isi dalam kurikulum perlu ditelaah betulbetul dan memasukkan nilai-nilai karakter moderasi Islam dalam kegiatan belajar mengajar (KBM) pada semua matapelajaran. Madrasah juga perlu menginsersi muatan moderasi Islam ke dalam program, kegiatan madrasah baik intra, ekstra maupun ko-kurikuler madrasah. Kegiatan ekstra kurikuler juga harus dirancang sedemikian rupa untuk memasukkan nilai-nilai karakter moderasi Islam. 
3. Optimalisasi habituasi dan budaya madrasah sebagai strategi internalisasi nilai-nilai karakter moderasi Islam.

Nilai-nilai karakter moderasi Islam tidak akan terinternalisasi secara mendalam hanya dengan mengajarkannya saja. Dibutuhkan pembiasaan secara terus-menerus dan konsisten sehingga menjadi budaya madrasah. Dalam konteks ini keteladanan menjadi metode pendidikan yang paling efektif. Kepala madrasah dan guru harus tampil menjadi figur panutan bagi peserta didik dalam menerapkan karakter moderasi Islam. Pembiasaan baik yang istikomah terkait misalnya adab berbicara dengan orang lain, tata cara bermuamalah dengan teman, guru dan warga madrasah yang lain, pembiasaan ibadah mahdloh dan ghoiru mahdloh akan membentuk kepribadian peserta didik.

4. Madrasah mengembangkan program penguatan moderasi Islam

Penguatan moderasi Islam melalui perancangan dan pelaksanaan program yang matang, konseptual, implementatif dan efektif perlu dikembangkan oleh madrasah untuk semakin mengukuhkan pengarusutamaan moderasi Islam di madrasah. Diantara program yang dapat dijalankan antara lain:

a. Program fasilitasi dan penciptaan ruang interaksi dan dialog lintas budaya.

Madrasah perlu mengkreasi atau setidaknya memfasilitasi kegiatan-kegiatan yang memberikan kesempatan berlangsungnya interaksi dan dialog lintas budaya, etnis bahkan agama. Program yang dapat dilaksanakan antara lain: program guru tamu (guest teacher) dari latar belakang etnis atau budaya yang berbeda, program kunjungan ke komunitas tertentu, program kegiatan bersama semisal kemah budaya. Dengan program-program tersebut diharapkan memberikan pengalaman berinteraksi dengan kelompok lain yang berbeda sehingga 
para siswa diharapkan tumbuh sikap penghargaan terhadap perbedaan dan toleransi.

b. Program penguatan literasi moderasi beragama

Program penguatan literasi berkaitan erat dengan pemerolehan informasi baik dari bahan tertulis maupun tidak tertulis. Madrasah perlu memfasilitasi peserta didik agar memperoleh kemudahan dalam akses informasi. Literasi ini juga dapat dimanfaatkan untuk memberikan motivasi dan spirit kebaikan. Misalnya madrasah dapat memasang tulisan semboyan atau ajakan dan motivasi sesuai karakter moderasi Islam, menyediakan bahan dan buku bacaan. Madrasah dapat pula mengagendakan penayangan film yang mengajarkan karakter moderasi Islam atau menggelar lomba bercerita pada momen dan even tertentu.

Beberapa tawaran model implementasi tersebut di atas dengan komitmen seluruh pemangku kepentingan madrasah diharapkan mampu mewujudkan pengarusutamaan moderasi Islam di madrasah sehingga pada gilirannya mampu mencetak peserta didik yang berkarakter moderat dan toleran.

\section{KESIMPULAN}

Dari pembahasan di atas dapat diambil kesimpulan sebagai berikut:

1. Moderasi (wasatiyyah) dapat dipahami sebagai keseimbangan antara keyakinan yang kokoh dengan toleransi yang di dalamnya terdapat nilai-nilai Islam yang dibangun atas dasar pola pikir yang lurus dan pertengahan serta tidak berlebihan. Keseimbangan tersebut bisa terlihat dengan kemampuan mensinergikan antara dimensi spiritualitas dengan material, individualitas dengan kolektivitas, tekstual dengan kontekstual, konsistensi dengan perubahan dan meletakkan amal di dalam prinsip-prinsip 
keseimbangan antara theocentris dan anthropocentris. Sedangkan pendidikan moderasi beragama adalah upaya sadar dalam memahami, menanamkan dan menumbuhkan pemahaman atas keberagaman agama, etnis, ras dan budaya melalui berbagai macam pendekatan, strategi dan metode yang tepat sehingga tumbuh sikap dan perilaku moderat yang tercermin dalam nilainilai moderasi beragama antara lain, penghargaan terhadap keragaman, toleransi, moderat, keseimbangan, dan keadilan pada diri setiap peserta didik.

2. Nilai-nilai karakter moderasi dalam Islam antara lain Tawassut (mengambil jalan tengah), Tawazun (berkesimbangan), I'tidal (lurus dan tegas), Tasamuh (Toleran), Musawah (egaliter), Syura (musyawarah), Ishlah (reformasi), Aulawiyah (mendahulukan yang prioritas), Tatawwur wa ibtikar (dinamis dan inovatif), Tahadhdhur (berkeadaban), Wathaniyah wa muwathanah, yaitu penerimaan eksistensi negara-bangsa (nation-state), Qudwatiyah, yaitu melakukan kepeloporan dalam prakarsa-prakarsa kebaikan demi kemaslahatan hidup manusia (common good and wellbeing).

3. Madrasah dipandang sebagai salah satu institusi pendidikan Islam yang relatif berhasil menanamkan Islam yang moderat. moderasi Islam dengan nilai karakternya sudah menjadi laku dan budaya segenap warga madrasah. Madrasah bisa menjadi contoh pendidikan moderasi beragama bagi institusi pendidikan lainnya. Untuk memantapkan madrasah dapat mengembangkan pengarusutamaan moderasi islam antara lain melalui: perumusan visi dan misi berorientasi moderasi Islam, pengembangan kurikulum yang komprehensif yang menginsersi nilai-nilai 
moderasi Islam, Optimalisasi habituasi dan budaya madrasah sebagai strategi internalisasi nilai-nilai karakter moderasi Islam, dan mengembangkan program penguatan moderasi Islam.

\section{DAFTAR PUSTAKA}

Ahnaf, M. I. (2013) 'Struktur politik dan deradikalisasi pendidikan agama bagi anak muda di Indonesia', Jurnal Pendidikan Islam. doi: 10.14421/jpi.2013.21.153-171.

Al-Munawwar, Said Agil Husain, Fikih Hubungan Antar Agama, (Jakarta: Ciputat Press, 2005).

Azca, M. N. (2013) 'Yang Muda, Yang Radikal: Refleksi Sosiologis Terhadap Fenomena Radikalisme Kaum Muda Muslim di Indonesia Pasca Orde Baru', Maarif, 8(1), pp. 1444.

BNPT (2016) Terkait Lone Wolf, kepala BNPT Minta Awasi Anak Muda. Available at: https://damailahindonesiaku.net/terkaitlone-wolf-kepala-bnpt-minta-awasi-anak-muda.html.

Hilmy, M. (2015) 'Anak Muda di Tengah Pusaran Radikalisme', Jawa Pos, 27 March. Available at: http://digilib.uinsby.ac.id/14245/1/Anak Muda Di Tengah Pusaran Radikalisme .pdf.

https://nasional.tempo.co/read/1118802/setara-institut-intoleransiterhadap-keyakinan-meningkat, diakses Kamis, 12 Nopember 2020 pukul 17.44 WIB.

https://nasional.tempo.co/read/1118802/setara-institut-intoleransiterhadap-keyakinan-meningkat, diakses Selasa, 17 Nopember 2020 pukul 17.44 WIB.

https://republika.co.id/berita/p639ta396/sebagai-garda-depanmoderasi-islam-ini-kelebihan-madrasah. Diakses Kamis, 12 Nopember 2020 pukul 23.52 WIB. 
https://www.merdeka.com/politik/lipi-temukan-fakta-intoleransimeningkat-di-indonesia.html, diakses Kamis, 12 Nopember 2020 Pukul 17.55 WIB.

Kantor Utusan Khusus Presiden untuk Dialog dan Kerjasama Antar Agama dan Peradaban, Wasatiyyat Islam Untuk Peradaban Dunia: Konsepsi dan Implementasi, (Jakarta: KUKP, 2018).

Langgulung, Hasan, Azas-azas Pendidikan Islam, (Jakarta: Pustaka AlHusna, 2003).

Madjid, Nurcholish, Pluralitas Agama: Kerukunan dalam Keragaman, (Jakarta: Kompas, 2001).

Manser, Martin H., Oxford Learner's Dictionary, (Oxford: Oxford University Press, 1991).

Murtadlo, M. (2019a) Menakar Moderasi Beragama pada Perguruan Tinggi, Kemenag.go.id. Murtadlo, M. (2019b) Seminari dan Pengembangan Moderasi Beragama: Kajian terhadap Seminari Al Kitab Asia Tenggara (SAAT) Malang. Jakarta. Puslitbang Penda

Nafis, M. Cholil dkk., Islam Wasathiyyah, (Jakarta: Komisi Dakwah MUI, 2019).

Nasikun, Sistem Sosial Indonesia, (Jakarta: Raja Grafindo Persada, 2007).

Rosyada, Dede Paradigma Pendidikan Demokratis, Sebuah Model pelibatan Masyarakat dalam Pendidikan, (Jakarta: Prenada Media, 2013).

Suardi, Moh., Ideologi Politik Pendidikan Kontemporer, (Yogyakarta: e-Publish, 2015).

Sutrisno, Edy, Aktualisasi Moderasi Beragama di Lembaga Pendidikan, dalam Jurnal Bimas Islam Vol 12 No. 1 (2019) http://jurnalbimasislam.kemenag.go.id 